\title{
A century of local changes in bumblebee communities and landscape composition in Belgium
}

\author{
Sarah Vray ${ }^{1,2,3} \cdot$ Orianne Rollin ${ }^{2,4}$ (1) $\cdot$ Pierre Rasmont $^{2} \cdot$ Marc Dufrêne $^{4} \cdot$ Denis Michez $^{2} \cdot$ Nicolas Dendoncker $^{3}$
}

Received: 9 June 2018 / Accepted: 25 February 2019 / Published online: 1 March 2019

(c) Springer Nature Switzerland AG 2019

\begin{abstract}
Bumblebees (Bombus spp.) are declining in most parts of Western Europe. Many studies have highlighted the role of agricultural intensification and urbanisation in this decline, and some have also shown the influence of landscape composition on bumblebee populations. However, very few studies have explored bumblebee communities prior to the onset of these major land use changes, and those studies that do are mostly based on low-resolution spatial data. Here, we perform a comparative analysis based on detailed landscape composition and bumblebee occurrence records between the early twentieth century (1910-1930) and the contemporary period (2013-2015) in four localities representative of Belgium. We show that bumblebee assemblages changed drastically over this period, and that the decline in richness was strongest in areas with the greatest increase in urbanization and agricultural intensification. The one locality still retaining a high proportion of grasslands, orchards and woodlands with the smallest overall change in landscape composition still hosts a rich bumblebee fauna, very similar than in the past. We provide recommendations for land use management based on these findings. We also warn about the importance of other factors such as land use intensity, climatic conditions and altitude, which should be included in any future study addressing changes in bumblebee populations related to land use changes.
\end{abstract}

Keywords Biodiversity $\cdot$ Community $\cdot$ Species richness $\cdot$ Agricultural practices $\cdot$ Conservation

\section{Introduction}

Numerous bumblebee (Bombus) species are undergoing a strong population decline in Western Europe and North America (Williams 1986; Rasmont et al. 2006; Biesmeijer

Electronic supplementary material The online version of this article (https://doi.org/10.1007/s10841-019-00139-9) contains supplementary material, which is available to authorized users.

Sarah Vray

sarah.vray@gmail.com

Orianne Rollin

orianne.rollin@gmail.com

1 Department of Environmental Research and Innovation, Luxembourg Institute of Science and Technology, Rue du Brill, 41, 4422 Belvaux, Luxembourg

2 Laboratory of Zoology, Research Institute of Biosciences, University of Mons, Place du Parc, 20, 7000 Mons, Belgium

3 Department of Geography, Research Group on Sustainable Development, University of Namur, Namur, Belgium

4 Biodiversity \& Landcapes, Gembloux Agro-Bio Tech, University of Liège, Gembloux, Belgium et al. 2006; Goulson et al. 2008; Williams and Osborne 2009; Cameron et al. 2011; Nieto et al. 2014). Among the 68 bumblebee species in Europe, 31 are decreasing, 20 are stable, and only nine present positive population trends and expansion of their distribution (Nieto et al. 2014). Population declines seem to be greater in the agricultural areas of Western-Europe than in the Mediterranean and mountainous regions where agriculture remains relatively extensive (Rasmont et al. 2006; Iserbyt et al. 2008), or is even in decline (Iserbyt et al. 2015). The alarming regression of bumblebees can be explained by several factors including climate change (Kerr et al. 2015), habitat loss and fragmentation, and the intensive use of agrochemical inputs (including pesticides), mostly resulting from the agricultural intensification seen since the 1950s (Kosior et al. 2007; Goulson et al. 2008; Williams et al. 2009). Agricultural landscapes, before the 1950s composed of small polycultures and grasslands rich in flowers separated by hedges and trees, gradually turned into homogeneous landscapes dominated by large monocultures, intensive pastures and frequently mown hayfields (Robinson and Sutherland 2002; Mazoyer and Roudart 2006). 
Most studies assessing the influence of land use on bumblebee communities are based only on contemporary data, and very few use data from before the onset of agricultural intensification, i.e. before 1950 (Senapathi et al. 2015; Mihoub et al. 2017; Aguirre-Gutiérrez et al. 2017). The few studies that do so often do not include high-resolution land cover data. One exception is a recent study in England (Senapathi et al. 2015), but its island fauna shows a lower species diversity and different population trends than the European continent, at the opposite of others studies reporting parallel developments on wild bees (e.g., Biesmeijer et al. 2006) and bumblebees (e.g. Carvalheiro et al. 2013) between Great Britain and the European continent.

The aim of this study is therefore to qualify and quantify the changes in bumblebee communities in relation to landscape changes that occurred during the last century (i.e. largescale agricultural intensification and urbanisation; Mihoub et al. 2017). Belgium is a particularly suitable area for this kind of study. It presents a typical example of agricultural intensification in Western Europe (Christians 1998), and its bumblebee fauna has been studied since the early nineteenth century (Meunier 1888; Ball 1914, 1920; Rasmont and Mersch 1988; Rasmont et al. 2006). Moreover, there has been a large increase in urbanization in different regions across the country. However, the effect on pollinator communities is still unclear. Some studies show a potentially negative effect of urbanization on pollinator communities and their interactions with plants and their reproductive success (Hennig and Ghazoul 2011; Geslin et al. 2013), while others show that citizen engagement can improve biodiversity and develop cities as a refuge for insect pollinators (i.e. Hall et al. 2017). Here, we perform a comparative analysis based on landscape composition and bumblebees occurrence records in the early twentieth century (1910-1930) and the contemporary period (2013-2015) in four localities representative of Belgium. These four localities were well sampled during the early twentieth century by F.J. Ball (Ball 1914, 1920) and were carefully resampled during 2013-2015. Landscape composition was analysed at a highresolution in each period and each locality. We predict that the strongest shifts in bumblebee communities during the last century occurred in landscapes where land use changed the most at a spatial scale relevant for bumblebees. Furthermore, we expect that specific land use types (e.g. heathland, grassland, woodland, orchards) are related to higher species richness than other types such as cropland and settlement.

\section{Materials and methods}

\section{Selection of the study area}

In this study, our goal was to assess the changes in bumblebee communities across a large temporal period (100 years).
To determine these temporal changes, we needed a dataset containing rare species as well as common ones. In order to detect rare species, we restricted our sampling to a small number of different localities. This allowed us to collect a large number of specimens, increasing the chance of collecting rare species. Secondly, chosen sites had to be sampled at different time periods in order to compare observed communities over time. Therefore, our locality selection was determined by the data available from past studies, where only a few localities were intensively sampled (Ball 1914, 1920). Finally, we targeted localities representing as much as possible the land cover diversity of Belgian biogeographical regions.

The final four selected localities (Moorsel, Trivières, Torgny, Francorchamps) are distributed across the country and represent the two main biogeographical regions of Belgium (Fig. 1) with different altitudes (30 $\mathrm{m}$ for Moorsel, $70 \mathrm{~m}$ for Trivières, $240 \mathrm{~m}$ for Torgny and $495 \mathrm{~m}$ for Francorchamps). They are very different in terms of land use, both in the past and in the present (Fig. 2; Table 1), with a landscape gradient from highly artificial, with a majority of urbanized and cultivated areas (e.g. Trivières) to highly forested (e.g. Francorchamps).

\section{Bumblebee dataset}

For past sampling (P1: 1910-1930), we obtained the bumblebee historic data by digitizing the F.J. Ball collection

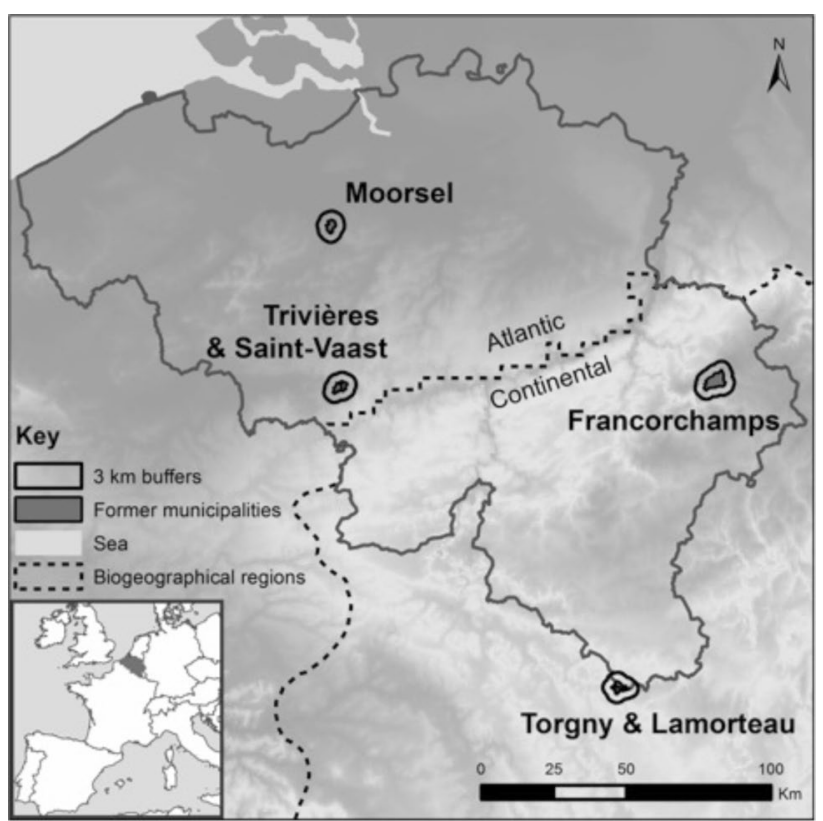

Fig. 1 Localization of the four sampling localities consisting in former municipalities (red zones) and their $3 \mathrm{~km}$ buffer (black circles). Trivières and Saint-Vaast are merged in "Trivières", and Torgny and Lamorteau are merged in "Torgny" in analyses. (Color figure online) 


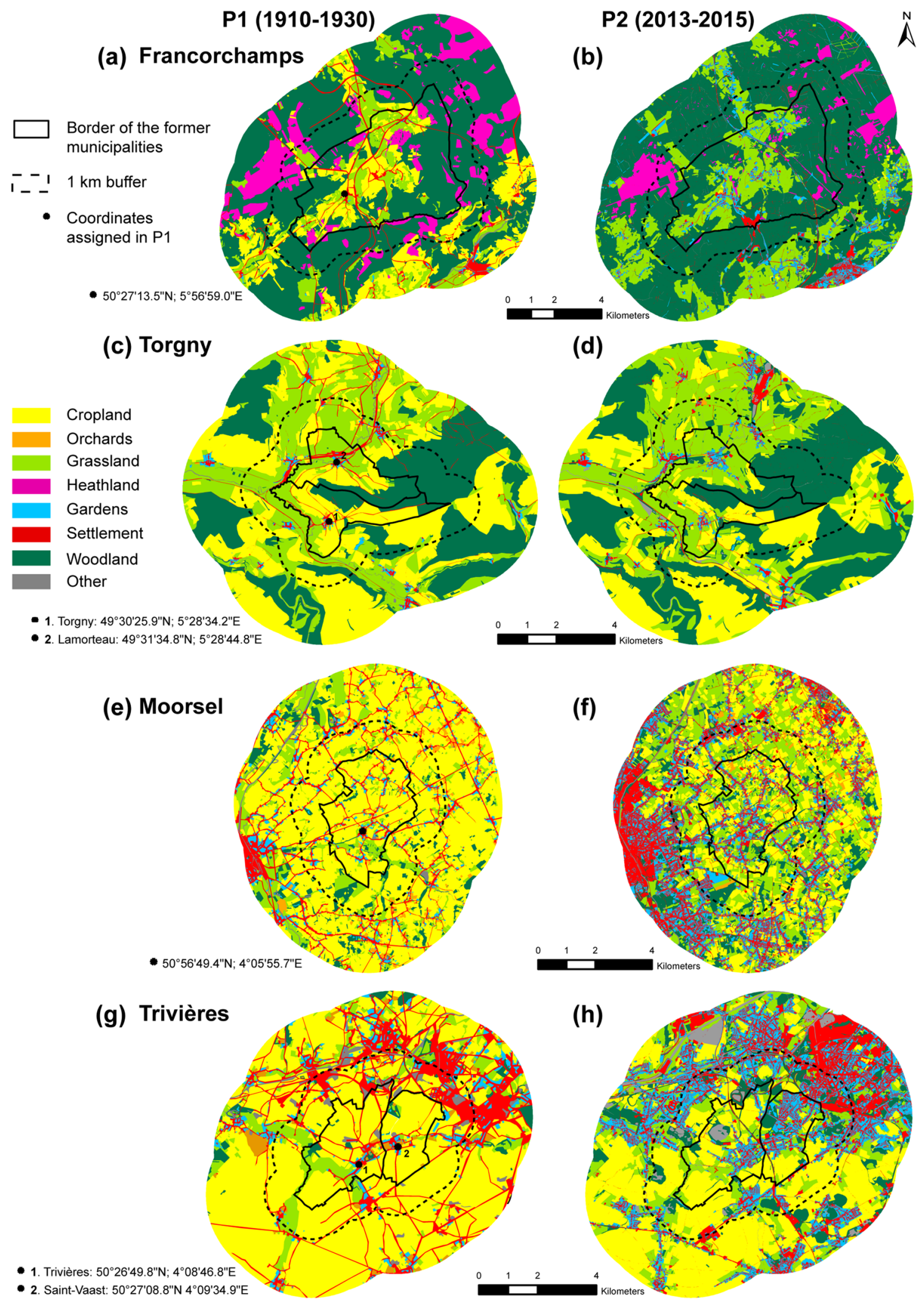

Fig. 2 Land cover in a 3 km buffer around the former municipalities of Francorchamps in P1 (a) and P2 (b), Torgny (and Lamorteau) in P1 (c) and P2 (d), Moorsel in P1 (e) and P2 (f), and Trivières (and Saint-Vaast) in P1 (g) and P2 (h) 
Table 1 Landscape composition of the four localities in hectares (and in percentage of the considered buffer) of the 8 land cover types in the $1-\mathrm{km}$ and 3-km buffers in the past period (P1: 1910-1930) and the present period (P2: 2013-2015)

\begin{tabular}{|c|c|c|c|c|c|c|c|c|}
\hline & \multicolumn{2}{|c|}{ Francorchamps } & \multicolumn{2}{|c|}{ Torgny } & \multicolumn{2}{|c|}{ Moorsel } & \multicolumn{2}{|c|}{ Trivières } \\
\hline & $\mathrm{P} 1$ & $\mathrm{P} 2$ & $\mathrm{P} 1$ & $\mathrm{P} 2$ & P1 & $\mathrm{P} 2$ & P1 & $\mathrm{P} 2$ \\
\hline \multicolumn{9}{|c|}{ Land cover area in $1 \mathrm{~km}$ buffer (\%) } \\
\hline Cropland & 14.6 & 0.1 & 35.6 & 21.0 & 71.4 & 28.9 & 67.0 & 37.8 \\
\hline Gardens & 0.1 & 3.8 & 1.3 & 3.0 & 4.1 & 17.2 & 3.6 & 18.5 \\
\hline Grassland & 12.7 & 21.1 & 30.6 & 37.9 & 10.8 & 33.7 & 8.8 & 15.4 \\
\hline Heathland & 11.6 & 4.8 & - & - & - & - & - & - \\
\hline Orchards & 0.1 & - & 0.5 & 0.5 & 2.3 & 1.9 & 1.5 & 0.1 \\
\hline Settlement & 3.6 & 4.7 & 4.4 & 3.2 & 6.2 & 8.2 & 14.5 & 14.7 \\
\hline Woodland & 57.2 & 65.1 & 26.6 & 33.1 & 5.0 & 9.9 & 1.6 & 11.0 \\
\hline Other & 0.1 & 0.4 & 1.0 & 1.3 & 0.2 & 0.2 & 3.1 & 2.5 \\
\hline \multicolumn{9}{|c|}{ Land cover area in $3 \mathrm{~km}$ buffer (\%) } \\
\hline Cropland & 15.0 & 0.2 & 36.8 & 25.3 & 64.1 & 25.3 & 65.2 & 36.8 \\
\hline Gardens & 0.2 & 4.5 & 1.1 & 1.9 & 4.8 & 20.5 & 4.3 & 18.6 \\
\hline Grassland & 11.1 & 20.6 & 26.8 & 31.5 & 12.5 & 28.1 & 8.1 & 14.5 \\
\hline Heathland & 13.5 & 6.3 & - & 0.1 & - & 0.1 & - & - \\
\hline Orchards & 0.2 & 0.1 & 0.4 & 0.2 & 3.4 & 1.8 & 2.2 & 0.1 \\
\hline Settlement & 4.0 & 5.1 & 3.1 & 2.9 & 8.4 & 13.4 & 15.3 & 17.9 \\
\hline Woodland & 55.8 & 62.7 & 31.1 & 37.2 & 5.7 & 10.0 & 2.4 & 9.0 \\
\hline Other & 0.2 & 0.5 & 0.7 & 0.9 & 1.1 & 0.8 & 2.5 & 3.1 \\
\hline
\end{tabular}

(Ball 1914, 1920) stored at the Royal Belgian Institute of Natural Sciences (RBINS) in Brussels (see Fig. S1 for the details per year).

For recent sampling, we collected bumblebees from 2013 to 2015 (P2) in the same four localities selected for the past period (P1). However, the sampling methods used by the collectors who contributed to the F.J. Ball collection are unknown, but probably consisted of unrestricted collections with nets in various habitat types (Ball 1914, 1920, Rasmont pers.comm). For this reason, we recorded bumblebees in as many habitat types as possible inside the municipalities (e.g. grasslands, woodlands, cropland edges, wood edges, roadsides). In the end, a total of 53 sites were sampled, including 10, 11, 13 and 19 sites respectively in Trivières, Moorsel, Torgny and Francorchamps localities. Each site was sampled for 3 days in 2013 and 2014 and 4 days in 2015. Sampling days were spread between March and September in order to record both early-emerging and late-emerging species, and the dates were chosen to be as close as possible to the dates sampled a century ago.

Sites were surveyed by capturing all bumblebees along a walking transect of $50 \mathrm{~m}$ long and $2 \mathrm{~m}$ wide (one of the most effective and widely used sampling protocol; see Westphal et al. 2008; Rollin et al. 2013, 2015). Bumblebees were captured with a net during suitable weather conditions for pollinators (minimum of $15^{\circ} \mathrm{C}$, no rain, dry vegetation, and a maximum of 6 on the Beaufort wind force scale; see also Westphal et al. 2008; Hoehn et al. 2010; Rollin et al. 2013, 2015). Each specimen was then identified by specialists (SV and PR) using a pair of binoculars following Rasmont and
Terzo (2010). In total, the final dataset consisted in 16,296 specimens in 1910-1930 (P1) and 3949 in 2013-2015 (P2).

\section{Characterization of landscape composition}

As the effects of landscape context on bumblebees differ according to spatial scale (Steffan-Dewenter et al. 2002; Westphal et al. 2006), we considered two buffers around the municipality border for land cover characterization. Based on the foraging range of bumblebees (WaltherHellwig and Frankl 2000; Kreyer et al. 2004; Knight et al. 2005; Greenleaf et al. 2007; Osborne et al. 2008a; Wolf and Moritz 2008; Hagen et al. 2011; Carvell et al. 2011), we considered a buffer of $1 \mathrm{~km}$, representing the maximum foraging range size of small species (e.g. Thoracobombus species), and a buffer of $3 \mathrm{~km}$, consisting in the maximum foraging range size of bigger species (e.g. B. terrestris and B. lapidarius).

For the 1910-1930 period (P1), we georeferenced and vectorised topographic maps at the scale of 1:20,000 from the "Institut Cartographique Militaire" (Fig. S2a,c), obtained from the "Institut Géographique National" (IGN) of Belgium. For the contemporary period (P2), we used the "Top10Vector" from the IGN of Belgium for 2012. Because Torgny is at the border of France (Fig. 1), we used aerial photographs from 1930 and orthophotos from 2012 from the French IGN in order to obtain land cover information for the French part of the area surrounding this locality. We manually classified land cover into eight types: cropland (including plants nurseries and small market producers), grassland 
(including hayfields), heathland (including moorland and peatland), gardens (including parks and lawns), orchards, settlement areas (including buildings, roads, and any bare surface), woodland, and others (water, marsh and swamp, rock, quarries, and sand). Finally, for each locality and buffer size, we calculated the relative area of each land cover type. All geographic analyses were performed using ArcGIS 10 software (ESRI 2011).

Finally, for each sampling period and locality, we collected information that could be used to interpret our results (e.g. type of crop, yield, population density).

\section{Characterization of the bumblebee communities}

Data were pooled within periods (P1: 1910-1930 and P2: 2013-2015) and localities (Moorsel, Trivières, Torgny and Francorchamps) for calculating total observed richness. In order to assess the sampling completeness of each locality for each time period, we performed individual-based rarefaction curves (Gotelli and Colwell 2001). We computed the expected (i.e. rarefied) species richness in random subsamples of 796 specimens (corresponding to the smallest sample size, see below) using the Hurlbert's index formula (Hurlbert 1971) and its standard error based on Heck et al. (1975).

Additionally, we calculated several indicators of species richness and diversity in each locality and for each time period, such as Shannon's diversity index (i.e. the uncertainty in identifying the species of an individual taken at random from the dataset, which reflects the richness and the evenness of the community) and 1-Simpson index, being the opposite of the Simpson index and corresponding to the probability that two individuals drawn at random are from different species. The diversity of the species community increases with the indexes of Shannon and 1-Simpson. We also calculated Berger-Parker's index, that represents the relative abundance of the most dominant species in the community (Berger and Parker 1970).

\section{Spatio-temporal variation in bumblebee communities}

We computed the Bray-Curtis dissimilarity coefficient (Bray and Curtis 1957) based on the logarithm of species abundances (i.e. number of specimens) to assess the compositional dissimilarity of bumblebee communities between localities and periods. We then represented the resulting dissimilarity matrix using a Principal Coordinates Analysis (PCoA, also known as Multidimensional Scaling). This distance-based statistical method allows choosing more adapted distance measurement for quantitative species data than the Euclidian distance in Principal Components Analysis or the $\chi^{2}$ distance in Correspondence Analysis (Legendre and Legendre 2012). In contrast to these two distances, the
Bray-Curtis dissimilarity coefficient does not take into account double-zeros and gives the same contribution to differences in abundant species than in rare species (Legendre and Legendre 2012). In order to visualize the differences between localities within the two periods separately, we also performed a PCoA for each period (see Fig. S4 and S5).

Finally, we calculated the differences in bumblebee expected richness between localities into the same period, and between periods into the same locality. We used Student's $t$-tests to determine whether the variation of the mean value of richness and composition dissimilarity (Bray-Curtis distances) of bumblebee communities were the same between localities than between periods. All analyses were performed using the R software version 3.4.2 (R Development Core Team 2017) and packages "vegan" (Oksanen et al. 2011) and "BiodiversityR" (Kindt and Coe 2005).

\section{Results}

\section{Changes in landscape use}

The four localities show very different landscape composition, with strong modifications between the two periods (Fig. 2; Table 1). Francorchamps is dominated by woodland and is the only locality showing a relatively high proportion of heathland, although this decreased by $50 \%$ between $\mathrm{P} 1$ and P2. Torgny is dominated by grassland, cropland and woodland. Moorsel and Trivières are dominated by cropland, gardens, grassland, and settlement areas. Changes between P1 and P2 show that cropland areas decreased sharply in all localities and were mainly replaced by gardens, grasslands (including pastures and mown grasslands), settlement and woodland. The same patterns were observed at the regional and national scales (Table S1). However, even if total production areas decreased, yield per hectare of all crop types greatly increased, representing a strong intensification of agriculture (Table S2). The area of settlements and gardens increased overall, but the western localities of the country (i.e. Moorsel and Trivières) showed a greater expansion of these areas with the highest increase in population density over the last century (gain of 2.90 and 1.18 inhabitants/ha in Moorsel and Trivières, against 0.12 and 0.05 in Francorchamps and Torgny, respectively). For Torgny, there was a decline in the area of settlements, which most likely results from differences in map detail for this land cover type. Indeed, the size of roads and urban areas are overestimated in older topographic maps, leading to an overestimation of settlement area in P1 and thus a probable underestimation of urbanisation between P1 and P2. Consequently, this decline should be interpreted more as stability than a decline, as reflected by the relatively stable population 
density in this locality ( 0.62 and 0.67 inhabitant/ha in P1 and $\mathrm{P} 2$, respectively).

\section{Changes in bumblebee species diversity}

A total of 29 species was recorded between 1910 and 1930, from 21 species in Torgny to 26 species in Francorchamps and Trivières (Table 2). This observed species richness fell to 19 species in 2013-2015, with large differences between the four localities. The disappeared species from our localities in P2 are classified as Threatened species in the IUCN Red List of threatened bee species (Nieto et al. 2014; Rasmont et al. 2015a): B. confuses, B. cullumanus, $B$. distinguendus, B. pomorum, B. subterraneus (Risk of Extinction); B. muscorum, B. ruderatus, B. veteranus, (Critically Endangered); B. magnus, (Endangered); B. jonellus, (Vulnerable) (see Table S3). Species rarefaction curves show an nearly complete plateau for P1 (excepted for Torgny) but not for P2 (Fig. S3), suggesting that our sampling probably did not achieve the maximum species richness in P2. Indeed, four to six times as many specimens were collected in P1 compared to P2, with around 5000 specimens collected at each locality during P1 with only around 1,000 specimens collected for each locality during P2. We therefore restrict our comparisons to the expected species richness in the same sample size (i.e. 796 specimens). All the localities show a decline in expected species richness, but with contrasting intensities (Table 2). Moorsel and Trivières show the strongest decline, while Francorchamps and especially Torgny show a more stable richness. The difference in expected species richness is greater between the two time periods at the same locality than between the localities for the same time period (Fig. 3). Moreover, differences in expected richness between localities are higher during P2 (2013-2015) than during P1 (1910-1930), which shows that species richness was spatially more homogenous in the past than it is presently.

\section{Changes in the composition of bumblebee communities}

Community composition and species dominance differ between localities and time periods (Fig. 4, Table S3). For both time periods, the dominant species was $B$. lapidarius in Torgny and B. pascuorum in the three other localities. However, even if the dominant species remained the same for both time periods, its proportion changed in different ways according to the locality (see the Berger-Parker's index in Table 2). In Moorsel and Trivières, the proportional abundance of the dominant species increased between P1 and P2, whereas it decreased in Francorchamps and Torgny.

Bray-Curtis dissimilarity coefficients calculated between the two time periods are not significantly different to

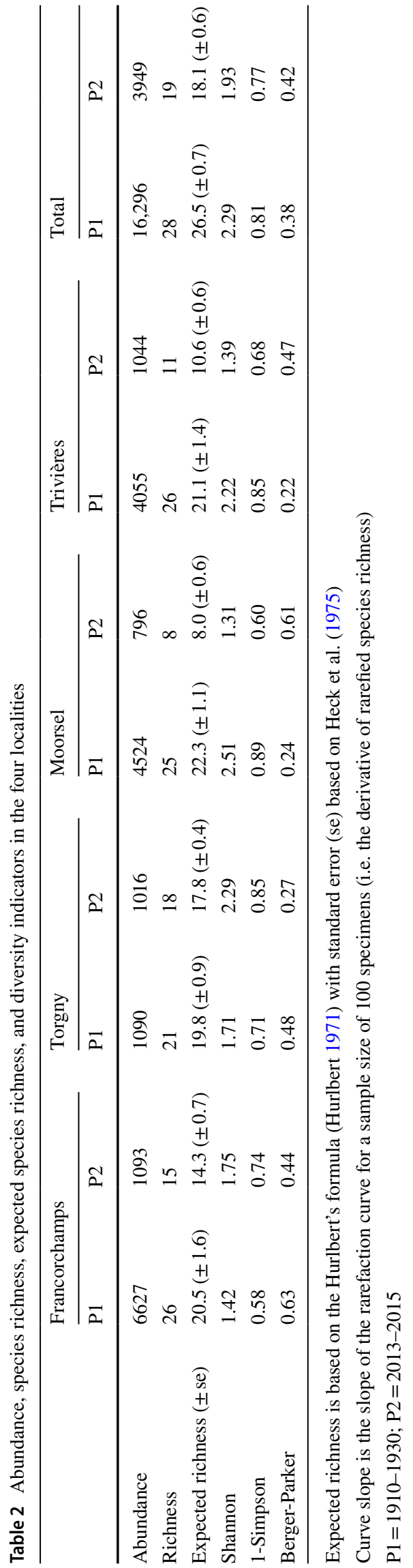




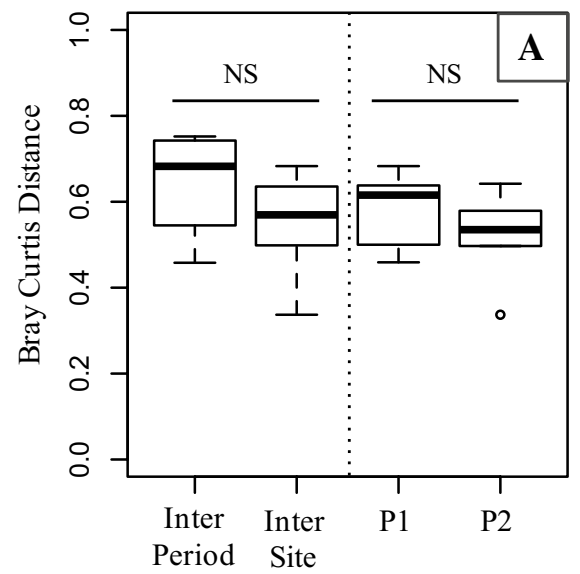

Fig. 3 Bray Curtis dissimilarity coefficients (BCd) (a), and difference in expected species richness in a sample of 796 specimens (b) between the two periods. Inter-period: $\mathrm{BCd}$ or Richness difference between $\mathrm{P} 1$ and $\mathrm{P} 2$ for each locality $(\mathrm{n}=4)$. Inter-site: $\mathrm{BCd}$ or richness difference between each pair of localities in a same sampling

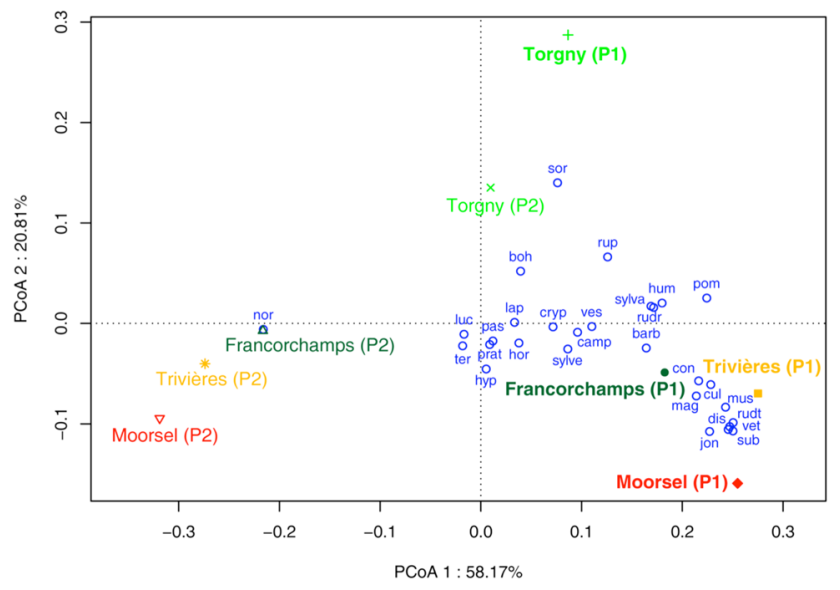

Fig. 4 Principal Coordinate Analysis graph of the Bray-Curtis dissimilarity matrix based on the logarithm of species abundances, with a posteriori projection of species (in blue) as weighted averages of their contributions to the sites. The two first components account for $78.98 \%$ of the total variance. barb $=B$. barbutellus, boh $=B$. bohemicus, camp $=B$. campestris, con $=B$. confusus, cryp $=B$. cryptarum, dis $=B$. distinguendus, hor $=B$. hortorum, hum $=B$. humilis, hyp $=B$. hypnorum, jon $=B$. jonellus, lap $=B$. lapidarius, luc $=B$. lucorum, $\mathrm{mag}=B$. magnus, mus $=B$. muscorum, nor $=B$. norvegicus, pas $=B$. pascuorum, pom $=B$. pomorum, prat $=B$. pratorum, $\operatorname{rudr}=B$. ruderarius, $\operatorname{rudt}=B$. ruderatus, $\operatorname{rup}=B$. rupestris, sor $=B$. soroeensis, $\mathrm{sub}=B$. subterraneus, sylva $=B$. sylvarum, sylve $=B$. sylvestris, ter $=B$. terrestris, ves $=B$. vestalis, vet $=B$. veteranus. (Color figure online)

coefficients calculated between localities for a given time period (Fig. 3). However, this could be due to the locality of Torgny, which presents a specific pattern. In addition to being the only site with a quite stable expected richness between P1 and P2 (Table 2), its bumblebee community has

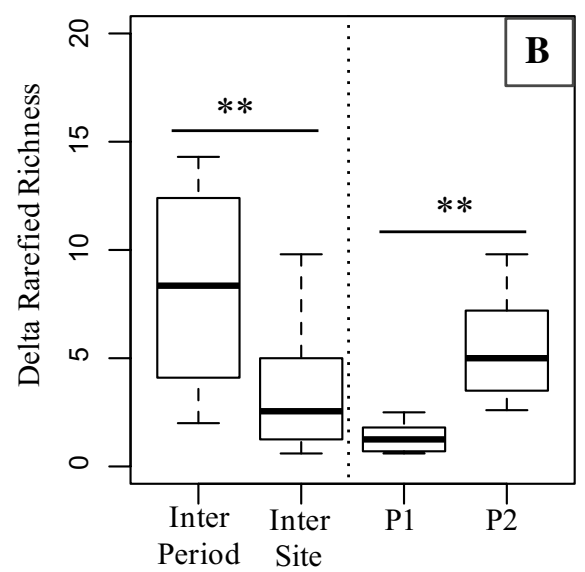

period $(\mathrm{n}=12) . P 1$ : $\mathrm{BCd}$ or richness difference between each pair of localities during P1 $(\mathrm{n}=6) . P 2$ : $\mathrm{BCd}$ or richness difference between each pair of localities during P2 $(n=6)$. Mean value comparisons was performed by tests of Student (NS not significant; *: $0.05>\mathrm{p}$ value $>0.01 ; * *: 0.01>p$ value $>0.001 ; * * * 0.001>p$ value $)$

a higher similarity between P1 and P2 than with other sites for a given time period (Table 3). These dissimilarities are visible on the PCoA graph (Fig. 4), which shows that only Torgny retained a similar bumblebee community to the ones found in the four localities a century ago.

\section{Discussion}

\section{Changes and intensification of land-use during the last century}

Land use drastically changed between the contemporary period and a century ago in most localities, with a similar pattern at the regional and national scales (Table S1), as well as the international scale as seen between 1930 and 2007 in England (Senapathi et al. 2015). Landscapes of a 100 years ago were dominated by low productivity crops, grasslands with low livestock density, orchards, and woodland sometimes associated with heathland. Settlements and gardens covered a relatively small percentage of the landscape.

During the last century, we observed a strong increase in grassland area (Table 1). This pattern is also highlighted at the global scale, as the share of global pasture grew from $2 \%$ of the world's surface area in 1700 to $24 \%$ in 2000 (34 million $\mathrm{km}^{2}$ ) (Klein Goldewijk et al. 2011). However, even if grassland areas (including pastures and mown grasslands) increased, their management is more intensive than in the past, with higher livestock densities and the addition of fertiliser to increase animal production, which decreases grassland quality (Barlow and Thorburn 2000). Generally, the remaining grasslands are usually turned into intensive 
Table 3 Bray-Curtis dissimilarity coefficient calculated between sites and time periods

\begin{tabular}{|c|c|c|c|c|c|c|c|}
\hline & \multicolumn{4}{|l|}{ P1 } & \multicolumn{3}{|l|}{$\mathrm{P} 2$} \\
\hline & Francor. & Torgny & Moorsel & Trivières & Francor. & Torgny & Moorsel \\
\hline \multicolumn{8}{|l|}{ P1 } \\
\hline Torgny & 0.633 & & & & & & \\
\hline Moorsel & 0.500 & 0.683 & & & & & \\
\hline Trivières & 0.598 & 0.638 & 0.459 & & & & \\
\hline \multicolumn{8}{|l|}{$\mathrm{P} 2$} \\
\hline Francor & 0.632 & & & & & & \\
\hline Torgny & & 0.458 & & & 0.560 & & \\
\hline Moorsel & & & 0.752 & & 0.510 & 0.642 & \\
\hline Trivières & & & & 0.733 & 0.497 & 0.579 & 0.337 \\
\hline
\end{tabular}

A value of 0 indicates a perfect similarity between assemblages, and a value of 1 indicates sites with no common species

Francor. Francorchamps

$\mathrm{P} 1=1910-1930 ; \mathrm{P} 2=2013-2015$ pastures or meadows mown early in the season for silage, which removes floral resources (Carvell 2002; Potts et al. 2010).

The area of cropland drastically decreased and were partly converted to grassland (as shown on our maps), as observed in other European countries, where $21 \%$ of all land use changes were caused by the conversion of cropland to grassland (Fuchs et al. 2015). In addition, the types of crops changed and the intensity of their management strongly increased in comparison with the early twentieth century (Ramankutty et al. 2002), with a threefold increase of yield per hectare (Table S2). In 1910, croplands in Trivières and Moorsel were dominated by low yielding cereal crops, leguminous plants (e.g. Trifolium pratense with 70 ha and 30 ha in Moorsel and Trivières respectively), potatoes (170 ha in Moorsel) and sugar beet (Ministère de l'Agriculture et des Travaux Publics 1913). They are now dominated by cereals, potatoes, and sugar beet with high productivity, but without value for pollinator communities, and with the total abandon of leguminous crops (Belgian Federal government 2017), which can provide a very valuable resource for bumblebees (Rasmont and Mersch 1988; Carvell et al. 2006; Rollin et al. 2013). Moreover, orchards have almost disappeared today (e.g. in Trivières), probably resulting from the Mansholt Plan in the 1970s, which strongly encouraged the felling of most orchards (Christians 1998).

However, a part of the strong increase in the area of grassland in our localities could be due to changes in grassland classification between pre-1930 and current maps. Maps of the past period (1910-1930) combined "artificial grasslands" (e.g. mown grasslands) with the crop fields into one class called "cultivated fields and artificial grasslands", while recent maps separate these two land cover types. Thus, for the contemporary period (2013-2015), it is therefore possible to combine mown grasslands with permanent grasslands (e.g. pastures), decreasing the percentage of crop areas to the detriment of grassland area. However, this change affects neither the results nor the observed trends, as shown by the agricultural statistics at the restricted scale of the municipality (Table S2). Overall, crops (notably cereals, clover, and alfalfa) and hayfields largely declined, while overgrazed pastures and settlement areas in highly urbanized areas increased.

Residual permanent elements, such as hedges, slopes and field margins managed with a late mowing, remain abundant in Francorchamps and Torgny. The hedgerows between pastures and hayfields are still well developed. However, heathland areas in Francorchamps decreased by half, as observed in England (Senapathi et al. 2015).

Finally, urbanisation, accompanied by an increase in population density, was the most intense in Moorsel and Trivières, with the highest expanding of settlement area and gardens. On the other hand, Torgny is the least affected by land cover and land use changes and its human population density barely increased.

\section{Spatio-temporal changes in bumblebee communities}

Our results show that observed and expected bumblebee species richness globally decreased at the study localities, respectively from 28 to 19 species and from 26.5 to 18.1 species, over a 100 year period. These results follow the trends observed both in Belgium and in Europe (Kosior et al. 2007; Carvalheiro et al. 2013; Nieto et al. 2014). A decrease in species richness and shifts in pollinator communities were also observed in $79 \%$ of the studied localities in England between 1930 and 2007 (Senapathi et al. 2015). In our results, the most severe decline is observed in the 
two western localities, Moorsel and Trivières (with respectively an expected richness decreasing from 22.3 to 21.1 in P1 to 8 and 10.6 species in P2), whereas the two eastern localities, Francorchamps and Torgny, tend to have a lower decline in expected richness (from 20.5 to 14.3 species in Francorchamps and from 19.8 to 17.8 species in Torgny). The dominant species (i.e. Bombus lapidarius in Torgny and B. pascuorum in others) remains the same in each locality between the two time periods but its dominance (i.e. relative abundance) increased in the western and decreased in the eastern localities. Differences between past and present expected bumblebee species richness in the same locality are higher than differences between localities in the same time period, indicating a strong change in bumblebee community composition over this time.

As seen in several previous studies (Pywell et al. 2006; Öckinger and Smith 2007; Hatfield and LeBuhn 2007; Ahrné et al. 2009; Le Féon et al. 2010; Deguines et al. 2016), we observed a higher bumblebee species expected richness in landscapes dominated by grasslands than in landscapes dominated by settlements, gardens, and intensive crops. Francorchamps and Torgny are the two localities with most grassland and woodland and harbour the highest expected species richness today. The high proportion of woodland at this two localities could explain the presence of some species preferring wooded habitats (Svensson et al. 2000; Rasmont et al. 2015a, b), such as B. norvegicus, B. lucorum and its parasite, B. bohemicus (Figs. 3, S5, Table S3).

However, regions dominated by woodland may be detrimental for species preferring open lands, such as $B$. ruderarius, $B$. rupestris, $B$. sylvarum and $B$. veteranus, which are associated with grasslands (Rasmont and Mersch 1988; Diaz-Forero et al. 2011). The highly wooded locality of Francorchamps harbours fewer expected species richness than Torgny and hosts the most generalist species (e.g. $B$. pascuorum, $B$. terrestris, $B$. lapidarius), few species preferring wooded habitats (e.g. B. lucorum), and few rarer species present thanks to its remaining heathland (i.e. B. cryptarum, B. soroeensis). Previous studies have shown that landscapes dominated by woodland do not support a great diversity of bumblebee species, but a small proportion of woodland around open habitats (i.e. grassland and heathland) is beneficial for many species because these woody habitats are good nesting and overwintering sites (Kells and Goulson 2003; Diaz-Forero et al. 2011, 2013).

Species sensitivity to land use change tends to be influenced by their ecological traits (Williams et al. 2010; De Palma et al. 2015). Generalist species such as B. hypnorum, $B$. lapidarius, B. pascuorum and B. terrestris, tend to be less sensitive to agriculture intensification and to urbanisation. These species are indeed among the only bumblebees still observed in Moorsel and Trivières in the recent samples (Table S3). Conversely, species specialized in more specific habitats or on particular plant species declined or disappeared when this irreplaceable resource decreased. It is the case of B. cryptarum, B. jonellus, and B. magnus, these species are specialized on heathland (Goulson et al. 2006; Kleijn and Raemakers 2008; Moquet et al. 2017) and were consequently more abundant in the only locality with heathland (i.e. Francorchamps) than in the others localities 100 years ago (Fig. 3, Table S3).

\section{Land use management to promote bumblebee populations}

Like many studies, our results can suggest that urbanisation (Ahrné et al. 2009), intensification of agriculture (Williams 1988; Mänd et al. 2001; Carvell 2002; Goulson et al. 2006; Le Féon et al. 2010) or both (Potts et al. 2010; Senapathi et al. 2015) are a threat to bumblebees, due to the loss of essential and favoured habitats.

The intensification of grasslands through intensive grazing and meadows mown early and more frequently in the season for silage, destroys the role for bumblebees and other pollinators by removing floral resources (Carvell 2002; Potts et al. 2010). Nitrogen fertilizers and herbicides used in crops and grassland indirectly affect bumblebees by reducing the diversity of plants (Kleijn et al. 2009), and therefore the diversity and availability of foraging resources (Roulston and Goodell 2011), such as thistles which are very important for the diet of male bumblebees (Vray et al. 2017). Moreover, grasslands at higher altitudes (like in Torgny and Francorchamps) have come under new pressures, such as corn crops for livestock feed but also for Christmas tree crops which use a lot of pesticides. Maintaining a high abundance and species richness of bumblebees requires a large proportion of permanent grassland, with more extensive management to promote a high quantity and diversity of flowers thorough the entire flight season of bumblebees (Pywell et al. 2006; Hatfield and LeBuhn 2007; Ahrné et al. 2009; Diaz-Forero et al. 2013).

However, the reinstatement of leguminous crops could provide a very valuable resource for bumblebees, many of which depending greatly on these plants (Rasmont and Mersch 1988; Carvell et al. 2006; Rollin et al. 2013). Indeed, Torgny, which is today the richest locality in bumblebee diversity among the four sampled localities, is the only one still presenting leguminous crops (mainly Trifolium pratense and Medicago sativa). Orchards could also represent good floral resources for bumblebee queens in the early season (Goulson et al. 2010).

Agricultural landscapes with residual undisturbed elements (e.g. hedges, slopes and field margins with late mowing) may harbour greater number of bumblebee colonies than homogenous landscapes (Banaszak 1992; Mänd et al. 2001; Croxton et al. 2002; Osborne et al. 2008b). Indeed, we 
observed the highest bumblebee expected richness in Francorchamps and Torgny where these residual semi-natural elements remain abundant, as shown in other studies (see Tscharntke et al. 2012). In addition, withered grass and tussocks found in hedges, wood edges and field boundaries with late mowing represent favourable nest sites and are used by nest-seeking queens (Svensson et al. 2000). Moreover, sowing bee-friendly plants on arable field margins tends to be favourable for bumblebees (Croxton et al. 2002; Pywell et al. 2006) and could improve floral resources availability closed to potential nest locations in intensive farmed localities such as Moorsel and Trivières.

Finally, even if urbanization is often considered as a threat for biodiversity, gardens and urban parks could be favourable for bumblebees and pollinators if they offer sufficient flower resources and nesting sites (McFrederick and LeBuhn 2006; Osborne et al. 2008b; Garbuzov et al. 2014; Normandin et al. 2017). Urban gardens are sometimes more favourable than semi-natural habitats in intensively farmland areas (Samnegard et al. 2011; Baldock et al. 2015) due to bee-friendly management such as low or no pesticide use, plant selection, and late mowing. It is important to improve their potential value for pollinators and to include them in conservation plans in addition to farmland areas. Some small adjustments are not very expensive and could be greatly helpful for bumblebee populations and other pollinators (Garbuzov et al. 2014). In the particularly urbanised and intensive landscapes such as Moorsel and Trivières, it is important to conserve elements that supply floral resources and nest sites for all bumblebee species in order to avoid the homogenisation of bumblebee communities as we observe today.

\section{Limitations of this study and recommendations for future research}

The first limitation of this study is the restricted number of studied localities. It is hazardous to draw strong conclusions from statistical analyses on the relationship between the changes in bumblebee communities and the changes in land cover based on four localities. Moreover, accumulation curves (Fig S2) show that the number of bumblebees recorded for each locality and period seems to be far from reaching asymptotes, especially during $\mathrm{P} 2$. This suggested that more sites were needed to complete the survey. Nevertheless, we could partly overcome this bias by estimating the expected species richness in the same sample size for all localities and periods. On another hand, the four localities present very different landscape compositions and dynamics and the area of some land cover types are correlated. The most wooded locality (Francorchamps) is the only one with heathland and has the lowest proportion of cropland.
Similarly, this most wooded locality is, with Torgny, the least urbanised. Furthermore, as each locality is situated in a distinct biogeographical region, other parameters such as altitude and probably climate are also important for explaining the variability observed in bumblebee communities between the sites. In 100 years, climate change probably had an impact on bumblebee communities in addition to land cover changes, and its effects may have differed between the four localities. As shown in other studies, climate has a pronounced impact on bumblebee communities (Rasmont et al. 2015a, b; Goulson et al. 2015; Aguirre-Gutiérrez et al. 2017) and may act in synergy with land use changes (Williams 1988; Williams et al. 2007; Brook et al. 2008; Tylianakis et al. 2008; Potts et al. 2010; Schweiger et al. 2010; Oliver and Morecroft 2014; Marshall et al. 2017). Furthermore, we highlighted that studying land cover dynamics alone cannot take into account the whole phenomenon of intensification of agriculture. It is important to consider information about agricultural practices (e.g. field rotation, frequency and period of meadow mowing). The amount, frequency of application and type of pesticides and fertilizers used in crops and grassland is also important information, but the lack of data on chemical input greatly limits this perspective. Future studies should take into account as much as possible the full range of factors such as land use, agricultural statistics, and climate in their analyses.

Another possible bias in our study could be the differences between the historic and recent sampling methods. Like most contemporary collectors in ecological studies, we sampled all bumblebee specimens encountered on a transect in a highly standardized protocol, while historic collectors were potentially biased towards specimens of particular interest, potentially shifting the historic collection towards rare species (e.g. see Carvalheiro et al. 2013). Therefore, past and present sampling may not have targeted the same species or habitats. For these reasons, it is important to be cautious in interpreting the results and in the conclusions, as in any study comparing past and contemporary periods.

\section{Conclusion}

Unlike other studies based mostly on contemporary data, our study explores changes in landscapes and bumblebee communities by using both historical data on land cover and bumblebee records going back to a period before the acceleration of urbanisation and agricultural intensification seen in the 1950s. Our results show a general decline of bumblebee communities with strong compositional shifts, which greatly vary between regions with different landscape dynamics. Changes in bumblebee communities were far less intense in regions where landscapes changed the least during the last century and a high density of natural habitats 
and a low density of settlement areas and intensive crops were conserved. In the highly urbanised and intensive agricultural landscapes, future land management could enhance bumblebee diversity by restoring landscape elements rich in floral and nesting resources, for example by reinstating leguminous crops, planting "bee-friendly" flowers and hedges, and by leaving areas unmown until late in the season. Our study shows the importance but also the limitations of historical data to inform our understanding of the effects of landscape-level changes on bumblebees, which could be useful for future land management and conservation biology.

Acknowledgements This research was supported by the Belgian Science Policy (Project BR/132/A1/BELBEES). We thank the Royal Belgian Institute of Natural Sciences of Brussels, especially W. Dekoninck and Y. Gerard, for the access to the F.J. Ball collection of bumblebees. We also want to thank T. Kervyn for his help in georeferencing the centenary topographic maps, as well as D. Brogna and C. De Montpellier d'Annevoie for their advice in the realization of land cover maps. For their help in sampling, we would like to thank N. Brasero, F. Colin, D. De Grave, M. De Munter, T. Delandsheer, C. Deschepper, D. Evrard, M. Folschweiller, M. Gérard, L. Krapf, T. Lecocq, F. Marlière, L. Marshall, B. Martinet, P. Raquez, and K. Schoonvaere. We also thank T. Wood for his proofreading.

\section{Compliance with ethical standards}

Conflict of interest The authors declare that they have no conflict of interest.

\section{References}

Aguirre-Gutiérrez J, Kissling WD, Biesmeijer JC et al (2017) Historical changes in the importance of climate and land use as determinants of Dutch pollinator distributions. J Biogeogr 44:696-707. https://doi.org/10.1111/jbi.12937

Ahrné K, Bengtsson J, Elmqvist T (2009) Bumble bees (Bombus spp) along a gradient of increasing urbanization. PLoS ONE 4:e5574. https://doi.org/10.1371/journal.pone.0005574

Baldock KCR, Goddard MA, Hicks DM et al (2015) Where is the UK's pollinator biodiversity? The importance of urban areas for flower-visiting insects. Proc Biol Sci. https://doi.org/10.1098/ rspb.2014.2849

Ball JF (1914) Les bourdons de la Belgique. Ann Soc Entomol Belgique 58:77-108

Ball JF (1920) Notes supplémentaires sur les bourdons de la Belgique. Bull Ann Soc Entomol Belgique 60:31-43

Banaszak J (1992) Strategy for conservation of wild bees in an agricultural landscape. Agr Ecosyst Environ 40:179-192. https://doi. org/10.1016/0167-8809(92)90091-O

Barlow T, Thorburn R (eds) (2000) Balancing conservation and production in grassy landscapes: proceedings of the Bushcare Grassy Landscapes Conference Clare, South Australia 19-21 August 1999. Environment Australia, Canberra

Belgian Federal government (2017) Statistics Belgium-Statistiques \& Chiffres. http://economie.fgov.be/fr/statistiques/chiffres/. Accessed 15 Feb 2017

Berger WH, Parker FL (1970) Diversity of planktonic foraminifera in deep-sea sediments. Science 168:1345-1347
Biesmeijer JC, Roberts SPM, Reemer M et al (2006) Parallel declines in pollinators and insect-pollinated plants in Britain and the Netherlands. Science 313:351-354. https://doi.org/10.1126/ science. 1127863

Bray JR, Curtis JT (1957) An ordination of the upland forest communities of Southern Wisconsin. Ecol Monogr 27:325-349. https ://doi.org/10.2307/1942268

Brook BW, Sodhi NS, Bradshaw CJA (2008) Synergies among extinction drivers under global change. Trends Ecol Evol (Amst) 23:453-460. https://doi.org/10.1016/j.tree.2008.03.011

Cameron SA, Lozier JD, Strange JP et al (2011) Patterns of widespread decline in North American bumble bees. Proc Natl Acad Sci 108:662-667. https://doi.org/10.1073/pnas.1014743108

Carvalheiro LG, Kunin WE, Keil P et al (2013) Species richness declines and biotic homogenisation have slowed down for NWEuropean pollinators and plants. Ecol Lett 16:870-878. https:// doi.org/10.1111/ele.12121

Carvell C (2002) Habitat use and conservation of bumblebees (Bombus spp.) under different grassland management regimes. Biol Conserv 103:33-49. https://doi.org/10.1016/S0006 $-3207(01) 00114-8$

Carvell C, Roy DB, Smart SM et al (2006) Declines in forage availability for bumblebees at a national scale. Biol Cons 132:481-489. https://doi.org/10.1016/j.biocon.2006.05.008

Carvell C, Jordan WC, Bourke AFG et al (2011) Molecular and spatial analyses reveal links between colony-specific foraging distance and landscape-level resource availability in two bumblebee species. Oikos 121:734-742. https://doi.org/10.111 1/j.1600-0706.2011.19832.x

Christians C (1998) Quarante ans de politique agricole européenne commune et d'agriculture en Belgique. Bull Soc Géograph Liège 35:41-55

Croxton PJ, Carvell C, Mountford JO, Sparks TH (2002) A comparison of green lanes and field margins as bumblebee habitat in an arable landscape. Biol Cons 107:365-374. https://doi.org/10.1016/S0006 -3207(02)00074-5

De Palma A, Kuhlmann M, Roberts SPM et al (2015) Ecological traits affect the sensitivity of bees to land-use pressures in European agricultural landscapes. J Appl Ecol 52:1567-1577. https://doi. org/10.1111/1365-2664.12524

Deguines N, Julliard R, Flores M de, Fontaine C (2016) Functional homogenization of flower visitor communities with urbanization. Ecol Evol 6:1967-1976. https://doi.org/10.1002/ece3.2009

Diaz-Forero I, Kuusemets V, Mänd M et al (2011) Effects of forest habitats on the local abundance of bumblebee species: a landscape-scale study. Baltic For 17:8

Diaz-Forero I, Kuusemets V, Mänd M et al (2013) Influence of local and landscape factors on bumblebees in semi-natural meadows: a multiple-scale study in a forested landscape. J Insect Conserv 17:113-125. https://doi.org/10.1007/s10841-012-9490-3

ESRI ESRI (2011) ArcGIS desktop. Redlands, California

Fuchs R, Herold M, Verburg PH et al (2015) Gross changes in reconstructions of historic land cover/use for Europe between 1900 and 2010. Glob Change Biol 21:299-313. https://doi.org/10.1111/ gcb. 12714

Garbuzov M, Ratnieks FLW, Thompson K (2014) Quantifying variation among garden plants in attractiveness to bees and other flower-visiting insects. Funct Ecol. https://doi. org/10.1111/1365-2435.12178

Geslin B, Gauzens B, Thébault E, Dajoz I (2013) Plant pollinator networks along a gradient of urbanisation. PLoS ONE 8(5):e63421. https://doi.org/10.1371/journal.pone.0063421

Gotelli NJ, Colwell RK (2001) Quantifying biodiversity: procedures and pitfalls in the measurement and comparison of species richness. Ecol Lett 4:379-391. https://doi.org/10.104 6/j.1461-0248.2001.00230.x 
Goulson D, Hanley ME, Darvill B, Ellis JS (2006) Biotope associations and the decline of bumblebees (Bombus spp.). J Insect Conserv 10:95-103. https://doi.org/10.1007/s10841-006-6286-3

Goulson D, Lye GC, Darvill B (2008) Decline and conservation of bumble bees. Annu Rev Entomol 53:191-208. https://doi. org/10.1146/annurev.ento.53.103106.093454

Goulson D, Lepais O, O'Connor S et al (2010) Effects of land use at a landscape scale on bumblebee nest density and survival. J Appl Ecol 47:1207-1215. https://doi.org/10.111 $1 / j .1365-2664.2010 .01872 . x$

Goulson D, Nicholls E, Botías C, Rotheray EL (2015) Bee declines driven by combined stress from parasites, pesticides, and lack of flowers. Science 347:1255957. https://doi.org/10.1126/scien ce. 1255957

Greenleaf SS, Williams NM, Winfree R, Kremen C (2007) Bee foraging ranges and their relationship to body size. Oecologia 153:589-596. https://doi.org/10.1007/s00442-007-0752-9

Hagen M, Wikelski M, Kissling WD (2011) Space use of bumblebees (Bombus spp.) revealed by radio-tracking. PLoS ONE 6:e19997. https://doi.org/10.1371/journal.pone.0019997

Hall DM, Camilo GR, Tonietto RK, Ollerton J, Ahrne K, Arduser M, Ascher JS, Baldock KCR, Fowler R, Frankie G, Goulson D, Gunnarsson B, Hanley ME, Jackson JI, Langellotto G, Lowenstein D, Minor ES, Philpott SM, Potts SG, Sirohi MH, Spevak EM, Stone GN, Threlfall CG (2017) The city as a refuge for insect pollinators. Conserv Biol 31:24-29. https://doi. org/10.1111/cobi.12840

Hatfield RG, LeBuhn G (2007) Patch and landscape factors shape community assemblage of bumble bees, Bombus spp. (Hymenoptera: Apidae), in montane meadows. Biol Cons 139:150158. https://doi.org/10.1016/j.biocon.2007.06.019

Heck KL, Belle G, Simberloff D (1975) Explicit calculation of the rarefaction diversity measurement and the determination of sufficient sample size. Ecology 56:1459-1461. https://doi. org/10.2307/1934716

Hennig EI, Ghazoul J (2011) Plant-pollinator interactions within the urban environment. Perspectives in plant ecology. evol syst 13:137-150

Hoehn P, Steffan-Dewenter I, Tscharntke T (2010) Relative contribution of agroforestry, rainforest and openland to local and regional bee diversity. Biodivers Conserv 19:2189-2200. https ://doi.org/10.1007/s10531-010-9831-z

Hurlbert SH (1971) The nonconcept of species diversity: a critique and alternative parameters. Ecology 52:577-586. https://doi. org/10.2307/1934145

Iserbyt S, Durieux E-A, Rasmont P (2008) The remarkable diversity of bumblebees (Hymenoptera: Apidae: Bombus) in the Eyne Valley (France, Pyrénées-Orientales). Ann Soc Entomol France (NS) 44:211-241. https://doi.org/10.1080/00379 271.2008.10697558

Iserbyt S, Vray S, Dendoncker N et al (2015) High-resolution distribution of bumblebees (Bombus spp.) in a mountain area marked by agricultural decline. Ann Soc Entomol France (NS) 51:375-391. https://doi.org/10.1080/00379271.2016.1141664

Kells AR, Goulson D (2003) Preferred nesting sites of bumblebee queens (Hymenoptera: Apidae) in agroecosystems in the UK. Biol Cons 109:165-174

Kerr JT, Pindar A, Galpern P et al (2015) Climate change impacts on bumblebees converge across continents. Science 349:177-180. https://doi.org/10.1126/science.aaa7031

Kindt R, Coe R (2005) Tree diversity analysis: a manual and software for common statistical methods for ecological and biodiversity studies. World Agroforestry Centre, Nairobi

Kleijn D, Raemakers IP (2008) A retrospective analysis of pollen host plant use by stable and declining bumblebee species. Ecology 89:1811-1823
Kleijn D, Kohler F, Báldi A et al (2009) On the relationship between farmland biodiversity and land-use intensity in Europe. Proc R Soc B 276:903-909. https://doi.org/10.1098/rspb.2008.1509

Klein Goldewijk K, Beusen A, Van Drecht G, De Vos M (2011) The HYDE 3.1 spatially explicit database of human-induced global land-use change over the past 12,000 years: HYDE 3.1 Holocene land use. Glob Ecol Biogeogr 20:73-86. https://doi.org/10.111 1/j.1466-8238.2010.00587.x

Knight ME, Martin AP, Bishop S et al (2005) An interspecific comparison of foraging range and nest density of four bumblebee (Bombus) species. Mol Ecol 14:1811-1820. https://doi.org/10.1111/ j.1365-294X.2005.02540.x

Kosior A, Celary W, Olejniczak P et al (2007) The decline of the bumble bees and cuckoo bees (Hymenoptera: Apidae: Bombini) of Western and Central Europe. Oryx 41:79-88. https://doi. org/10.1017/S0030605307001597

Kreyer D, Oed A, Walther-Hellwig K, Frankl R (2004) Are forests potential landscape barriers for foraging bumblebees? Landscape scale experiments with Bombus terrestris agg. and Bombus pascuorum (Hymenoptera, Apidae). Biol Cons 116:111-118. https ://doi.org/10.1016/S0006-3207(03)00182-4

Le Féon V, Schermann-Legionnet A, Delettre Y et al (2010) Intensification of agriculture, landscape composition and wild bee communities: a large scale study in four European countries. Agr Ecosyst Environ 137:143-150. https://doi.org/10.1016/j. agee.2010.01.015

Legendre P, Legendre LFJ (2012) Numerical ecology. Elsevier, Amsterdam

Mänd M, Sepp K, Truu J (2001) Landscape structure and bumble bee communities. Acta Hort 561:159-163. https://doi.org/10.17660/ ActaHortic.2001.561.23

Marshall L, Biesmeijer JC, Rasmont P et al (2017) The interplay of climate and land use change affects the distribution of EU bumblebees. Glob Change Biol 24:101-116. https://doi.org/10.1111/ gcb. 13867

Mazoyer M, Roudart L (2006) A history of world agriculture I from the neolithic age to the current crisis I Taylor \& Francis Group. Monthly Review Press, New York

McFrederick QS, LeBuhn G (2006) Are urban parks refuges for bumble bees Bombus spp. (Hymenoptera: Apidae)? Biol Conserv 129:372-382. https://doi.org/10.1016/j.biocon.2005.11.004

Meunier F (1888) Tableau dichotomique des Espèces, variétés Belges du Genre Bombus. Latreille Nat Sicil 7:173-176

Mihoub J-B, Henle K, Titeux N et al (2017) Setting temporal baselines for biodiversity: the limits of available monitoring data for capturing the full impact of anthropogenic pressures. Sci Rep 7:41591. https://doi.org/10.1038/srep41591

Ministère de l'Agriculture et des Travaux Publics (2013) Recensement général de 1910. In: Statistiques de la Belgique : Agriculture. Bruxelles

Moquet L, Vanderplanck M, Moerman R et al (2017) Bumblebees depend on ericaceous species to survive in temperate heathlands. Insect Conserv Divers 10:78-93. https://doi.org/10.1111/ icad.12201

Nieto A, Roberts SPM, Kemp J et al (2014) European red list of bees. Publications Office, Luxembourg

Normandin É, Vereecken NJ, Buddle CM, Fournier V (2017) Taxonomic and functional trait diversity of wild bees in different urban settings. PeerJ 5:e3051. https://doi.org/10.7717/peerj.3051

Öckinger E, Smith HG (2007) Semi-natural grasslands as population sources for pollinating insects in agricultural landscapes. J Appl Ecol 44:50-59. https://doi.org/10.1111/j.1365-2664.2006.01250.x

Oksanen J, Blanchet FG, Kindt R et al (2011) Vegan: community ecology package

Oliver TH, Morecroft MD (2014) Interactions between climate change and land use change on biodiversity: attribution problems, risks, 
and opportunities. Wiley Interdiscip Rev 5:317-335. https://doi. org/10.1002/wcc. 271

Osborne JL, Martin AP, Carreck NL et al (2008a) Bumblebee flight distances in relation to the forage landscape. J Anim Ecol 77:406415. https://doi.org/10.1111/j.1365-2656.2007.01333.x

Osborne JL, Martin AP, Shortall CR et al (2008b) Quantifying and comparing bumblebee nest densities in gardens and countryside habitats. J Appl Ecol. https://doi.org/10.111 1/j.1365-2664.2007.01359.x

Potts SG, Biesmeijer JC, Kremen C et al (2010) Global pollinator declines: trends, impacts and drivers. Trends Ecol Evol 25:345353. https://doi.org/10.1016/j.tree.2010.01.007

Pywell RF, Warman EA, Hulmes L et al (2006) Effectiveness of new agri-environment schemes in providing foraging resources for bumblebees in intensively farmed landscapes. Biol Cons 129:192206. https://doi.org/10.1016/j.biocon.2005.10.034

R Development Core Team (2017) R: A language and environment for statistical computing, version 3.4.2. R Foundation for Statistical Computing, Vienna, Austria. ISBN 3-900051-07-0

Ramankutty N, Foley JA, Olejniczak NJ (2002) People on the Land: changes in global population and croplands during the 20th century. AMBIO 31:251-257. https://doi. org/10.1579/0044-7447-31.3.251

Rasmont P, Mersch P (1988) First estimation of faunistic drift by bumblebees of Belgium, (Hymenoptera: Apidae). Ann Soc. R Zool Belgique 118:141-147

Rasmont P, Terzo M (2010) Catalogue et clé des sous-genres et espèces du genre Bombus de Belgique et du nord de la France (Hymenoptera, Apoidea). Université de Mons, Laboratoire de Zoologie, Belgium

Rasmont P, Pauly A, Terzo M et al (2006) The survey of wild bees (Hymenoptera, Apoidea) in Belgium and France. Rome, Italy

Rasmont P, Roberts S, Cederberg B et al (2015a) Bombus. Version 3.1. The IUCN red list of threatened species 2015. http://www. iucnredlist.org

Rasmont P, Franzén M, Lecocq T et al (2015b) Climatic risk and distribution atlas of European Bumblebees. BIORISK 10:1-236. https ://doi.org/10.3897/biorisk.10.4749

Robinson RA, Sutherland WJ (2002) Post-war changes in arable farming and biodiversity in Great Britain. J Appl Ecol 39:157-176. https://doi.org/10.1046/j.1365-2664.2002.00695.x

Rollin O, Bretagnolle V, Decourtye A et al (2013) Differences of floral resource use between honey bees and wild bees in an intensive farming system. Agr Ecosyst Environ 179:78-86. https://doi. org/10.1016/j.agee.2013.07.007

Rollin O, Bretagnolle V, Fortel L et al (2015) Habitat, spatial and temporal drivers of diversity patterns in a wild bee assemblage. Biodivers Conserv 24:1195-1214. https://doi.org/10.1007/s1053 1-014-0852-x

Roulston TH, Goodell K (2011) The role of resources and risks in regulating wild bee populations. Annu Rev Entomol 56:293-312. https://doi.org/10.1146/annurev-ento-120709-144802

Samnegard U, Persson A, Smith H (2011) Gardens benefit bees and enhance pollination in intensively managed farmland. Biol Cons 144:2602-2606. https://doi.org/10.1016/j.biocon.2011.07.008

Schweiger O, Biesmeijer JC, Bommarco R et al (2010) Multiple stressors on biotic interactions: how climate change and alien species interact to affect pollination. Biol Rev 85:777-795. https://doi. org/10.1111/j.1469-185X.2010.00125.x
Senapathi D, Carvalheiro LG, Biesmeijer JC et al (2015) The impact of over 80 years of land cover changes on bee and wasp pollinator communities in England. Proc R Soc B 282:20150294. https://doi. org/10.1098/rspb.2015.0294

Steffan-Dewenter I, Münzenberg U, Christof B et al (2002) Scaledependent effects of landscape context on three pollinator guilds. Ecology 83:1421-1432. https://doi.org/10.2307/3071954

Svensson B, Lagerlöf J, Svensson G B (2000) Habitat preferences of nest-seeking bumble bees (Hymenoptera: Apidae) in an agricultural landscape. Agr Ecosyst Environ 77:247-255. https://doi. org/10.1016/S0167-8809(99)00106-1

Tscharntke T, Tylianakis JM, Rand TA et al (2012) Landscape moderation of biodiversity patterns and processes-eight hypotheses. Biol Rev 87:661-685. https://doi.org/10.1111/j.1469185X.2011.00216.X

Tylianakis JM, Didham RK, Bascompte J, Wardle DA (2008) Global change and species interactions in terrestrial ecosystems. Ecol Lett 11:1351-1363. https://doi.org/10.1111/j.1461-0248.2008.01250.x

Vray S, Lecocq T, Roberts SPM, Rasmont P (2017) Endangered by laws: potential consequences of regulations against thistles on bumblebee conservation. Ann Soc Entomol France (NS) 53(1):33-41. https://doi.org/10.1080/00379271.2017.1304831

Walther-Hellwig K, Frankl R (2000) Foraging habitats and foraging distances of bumblebees, Bombus spp. (Hym., Apidae), in an agricultural landscape. J Appl Entomol 124:299-306. https://doi.org /10.1046/j.1439-0418.2000.00484.x

Westphal C, Steffan-Dewenter I, Tscharntke T (2006) Bumblebees experience landscapes at different spatial scales: possible implications for coexistence. Oecologia 149:289-300

Westphal C, Bommarco R, Carré G et al (2008) Measuring bee diversity in different european habitats and biogeographical regions. Ecol Monogr 78:653-671. https://doi.org/10.1890/07-1292.1

Williams PH (1986) Environmental change and the distributions of British bumble bees (Bombus Latr.). Bee World 67:50-61

Williams PH (1988) Habitat use by bumble bees (Bombus spp.). Ecol Entomol 13:223-237

Williams PH, Osborne JL (2009) Bumblebee vulnerability and conservation world-wide. Apidologie 40:367-387. https://doi. org/10.1051/apido/2009025

Williams PH, Araújo MB, Rasmont P (2007) Can vulnerability among British bumblebee (Bombus) species be explained by niche position and breadth? Biol Cons 138:493-505

Williams P, Colla S, Xie Z (2009) Bumblebee vulnerability: common correlates of winners and losers across three continents. Conserv Biol 23:931-940. https://doi.org/10.1111/j.1523-1739.2009.01176 .X

Williams NM, Crone EE, Roulston TH et al (2010) Ecological and life-history traits predict bee species responses to environmental disturbances. Biol Cons 143:2280-2291. https://doi.org/10.1016/j. biocon.2010.03.024

Wolf S, Moritz RFA (2008) Foraging distance in Bombus terrestris L. (Hymenoptera: Apidae). Apidologie 39:419-427. https://doi. org/10.1051/apido:2008020

Publisher's Note Springer Nature remains neutral with regard to jurisdictional claims in published maps and institutional affiliations. 